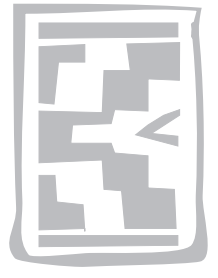

\title{
Curtisia dentata (Cornaceae) leaf extracts and isolated compounds inhibit motility of parasitic and free-living nematodes
}

\author{
L.J. SHAI ${ }^{1,2 *}$, E.S. BIZIMENYERA ${ }^{1,3}$, V. BAGLA ${ }^{1}$, L.J. MCGAW ${ }^{1}$ and J.N. ELOFF ${ }^{1}$
}

\begin{abstract}
SHAI, L.J., BIZIMENYERA, E.S., BAGLA, A.V., McGAW, L.J. \& ELOFF, J.N. 2009. Curtisia dentata (Cornaceae) leaf extracts and isolated compounds inhibit motility of parasitic and free-living nematodes. Ondesterpoort Journal of Veterinary Research, 76:249-256

Haemonchus contortus and Trichostrongylus colubriformis are among the most important parasitic nematodes of small ruminants. Caenorhabditis elegans, a free-living nematode, is used as a model for evaluating anthelmintic activity of a variety of test substances. Extracts of several medicinal plants are useful in vitro and in vivo against nematode development. Extracts of Curtisia dentata, a South African medicinal plant, and compounds isolated from leaves of this plant were investigated for anthelmintic activity against $T$. colubriformis, $H$. contortus and $C$. elegans. The acetone and dichloromethane extracts were active against all nematodes at concentrations as low as $160 \mu \mathrm{g} / \mathrm{ml}$. Betulinic acid and lupeol were active against the parasitic nematodes only at the high concentrations of 1000 and $200 \mu \mathrm{g} / \mathrm{m} \ell$, respectively. All compounds were effective against $C$. elegans with active concentrations as low as $8 \mu \mathrm{g} / \mathrm{ml}$. Betulinic acid was less active than lupeol and ursolic acid against $C$. elegans. The acetone and dichloromethane extracts were also active against $C$. elegans with a concentration of $0.31 \mathrm{mg} / \mathrm{ml}$ resulting in almost $80 \%$ inhibition of larval motility. The use of free-living nematodes may provide information on the activity of potential anthelmintics against parasitic nematodes. Extracts of various medicinal plant species may provide solutions to ill-health of small ruminants caused by parasitic nematodes in poor communities of southern Africa.
\end{abstract}

Keywords: Anthelmintic, betulinic acid, Curtisia dentata, lupeol, ursolic acid

\section{INTRODUCTION}

Helminthosis, caused by parasitic gastrointestinal nematodes, remains a major constraint to livestock

1 Phytomedicine Programme, Department of Paraclinical Sciences, Faculty of Veterinary Science, University of Pretoria, Private Bag X04, Onderstepoort, 0110 South Africa

2 Department of Biochemistry, Faculty of Science and Agriculture, University of Limpopo, P.O. Box 235, Medunsa, 0204 South Africa

3 Department of Agriculture and Animal Health, UNISA, Private Bag X6, Florida 1710

* Author to whom correspondence is to be directed. Email: ljshai@ul.ac.za

Accepted for publication 13 October 2008-Editor production across the tropical and subtropical regions, with Haemonchus contortus and Trichostrongylus colubriformis listed among the top ten most important parasites of ruminants (Perry \& Randolph 1999; Chiejina 2001; Hounzangbe-Adote, Paolini, Fouraste, Moutairou \& Hoste 2005). Trichostrongylus colubriformis causes parasitic enteritis that predisposes ruminants to diarrhoea, weakness and death. This parasite is frequently found infecting cattle and sheep in South Africa, causing loss in production (Horak 2003; Horak, Evans \& Purnell 2004). Haemonchus contortus causes anaemia, haemorrhagic gastroenteritis, hypoproteinaemia partly manifested as submandibular oedema or 'bottle jaw' and sudden death, or chronic emaciation 
in affected livestock (Urquhart, Armour, Duncan, Dunn \& Jennings 1996). In southern Benin, the prevalence of $H$. contortus was estimated at $92.5 \%$ in goats and sheep (Salifou 1996).

The usual mode of control of these parasitic diseases relies on the repeated and strategic use of proprietary anthelmintic drugs. However, these drugs are often so highly priced that they are not accessible to subsistence and small-scale livestock farmers in developing countries (Hounzangbe-Adote et al. 2005). Extensive use of drugs by commercial farmers has created anthelmintic resistance that has become cosmopolitan. The emergence of resistance of gastrointestinal nematodes to conventional anthelmintics and resulting economic and production losses emphasize the need to search for alternative methods of worm control (Prichard 1990; Wolstenholme, Fairweather, Prichard, Von SamsonHimmelstjerna \& Sangster 2004; Jabbar, Iqbal, Kerboeuf, Muhammad, Khan \& Afaq 2006).

One of the alternative methods of worm control is the use of medicinal plants. In many parts of the developing world, small-scale and subsistence farmers rely on traditional methods of deworming that include the administration of remedies derived from plants (Hammond, Fielding \& Bishop 1997; Danø \& Bøgh 1999). The scientific evidence of the efficacy and safety to support widespread use of plant-based remedies as anthelmintics is still scanty (Hammond et al. 1997). Extracts of several African plant species are active against parasitic and free-living nematodes (Hammond et al. 1997; Enwerem, Okogun, Wambebe, Okorie \& Akah 2001; Bizimenyera, Githiori, Eloff \& Swan 2006). Extracts of Artemisia sp. have shown activity against Haemonchus sp. (Idris, Adam \& Tartour 1982; Iqbal, Lateef, Ashraf \& Jabbar 2004) and Trichostrongylus species (Sharma 1993). Furthermore, Hördegen, Hertzberg, Heilmann, Langhans \& Maurer (2003) demonstrated anthelmintic activity of ethanolic extracts of several plant species in an in vivo sheep model.

Some compounds and plant extracts that possess anthelmintic activity also have antifungal efficacy. In 1993, Padmaja, Thankamany \& Hisham reported that extracts of the root bark of Uvaria hookeri and Uvaria narum, together with the isolated acetogenins, have antifungal, antibacterial and anthelmintic activities. Benzimidazole carbamates, a class of anthelmintics used in human and veterinary medicine have antifungal activity (Murray, Hudson \& Yassa 1992; Katiyar, Gordon, McLaughlin \& Edlind 1994). Polyphenols isolated from the leaves of Piper betle had both antifungal and anthelmintic activity (Evans,
Bowers \& Funk 1984). The extracts of $C$. dentata leaves showed antifungal activity against Candida albicans and several other fungal species (Shai 2007; Shai, McGaw, Masoko \& Eloff 2008). We investigated anthelmintic activity in $C$. dentata extracts and compounds isolated from the leaves of the plant to discover potential correlations with known antifungal activity.

Curtisia dentata is traditionally used in humans for stomach ailments and diarrhoea, as a blood strengthener and an aphrodisiac (Hutchings, Scott, Lewis \& Cunningham 1996; Pujol 2000). It is also used in the treatment of heartwater in cattle in the Eastern Cape Province (Dold \& Cocks 2001) and as a pimple treatment (Grierson \& Afolayan 1999). The anthelmintic activity of $C$. dentata extracts has not been reported in available literature. Betulinic acid is one of the compounds isolated from $C$. dentata leaves (Shai 2007). Betulinic acid is active against Caenorhabditis elegans, a free-living nematode, at a concentration of $500 \mu \mathrm{g} / \mathrm{ml}$ after 7 days of incubation (Enwerem et al. 2001). The dichloromethane and acetone extracts of $C$. dentata leaves, containing high concentrations of betulinic acid, were selected for investigation of their anthelmintic activity against the parasitic nematodes $T$. colubriformis and $H$. contortus, and the free-living $C$. elegans. Betulinic acid and two other compounds isolated from the leaves of $C$. dentata, ursolic acid and lupeol, were also tested for anthelmintic activity. This study was aimed at investigating whether the extracts of the leaves of $C$. dentata and compounds from it, which have shown antifungal activity (Shai 2007), also have anthelmintic activity.

\section{MATERIALS AND METHODS}

\section{Plant extracts and compounds}

Plant leaves were collected from the Lowveld $\mathrm{Na}$ tional Botanical Garden in Nelspruit, South Africa in woven sacks and dried at room temperature prior to powdering in a laboratory mill. A herbarium specimen, Shai 002, was deposited in the medicinal plant herbarium at the University of Pretoria (Department of Paraclinical Sciences). Powdered leaves (837 g) of $C$. dentata were serially extracted with hexane, dichloromethane, acetone and methanol, and compounds were isolated from the dichloromethane extract as previously described (Shai 2007). Aliquots of the dichloromethane and acetone extracts were dissolved in DMSO to a concentration of $100 \mathrm{mg} / \mathrm{ml}$. Stock solutions of $2 \mathrm{mg} / \mathrm{ml}$ of the isolated compounds betulinic acid, lupeol and ursolic acid were 
also prepared in DMSO. Preliminary tests confirmed that the final concentration of DMSO used in the assays was not toxic to the nematodes.

\section{Anthelmintic activity \\ Caenorhabditis elegans}

Caenorhabditis elegans was maintained in sterile Petri-dishes on Nematode Growth (NG) agar (composition per litre: $3 \mathrm{~g} \mathrm{NaCl}, 2.5 \mathrm{~g}$ peptone, $17 \mathrm{~g}$ agar, $5 \mathrm{mg}$ cholesterol, $0.246 \mathrm{~g} \mathrm{MgSO}_{4} .7 \mathrm{H}_{2} \mathrm{O}, 0.147 \mathrm{~g}$ $\mathrm{CaCl}_{2} \cdot 2 \mathrm{H}_{2} \mathrm{O}$, $2.7 \mathrm{~g} \mathrm{KH}_{2} \mathrm{PO}_{4}$, and $0.9 \mathrm{~g} \mathrm{~K}_{2} \mathrm{HPO}_{4}$ ) seeded with Escherichia coli (Brenner 1974). The nematodes were incubated at $20^{\circ} \mathrm{C}$ in the dark for 6 days prior to the anthelmintic assay which was performed using the method of Rasoanaivo \& Ratsimamanga-Urverg (1993) modified by McGaw, Jäger \& Van Staden (2000). Several plates were washed with $1 \mathrm{ml}$ M9 buffer (composition per litre: $6 \mathrm{~g}$ $\mathrm{Na}_{2} \mathrm{HPO}_{4}, 3 \mathrm{~g} \mathrm{KH}_{2} \mathrm{PO}_{4}, 5 \mathrm{~g} \mathrm{NaCl}$ and $0.25 \mathrm{~g}$ $\mathrm{MgSO}_{4} \cdot 7 \mathrm{H}_{2} \mathrm{O}$ ) to obtain a solution of approximately 100 nematodes per $10 \mu \ell$. Into 24-well plates, $2 \mathrm{m \ell}$ of plant extracts or compounds dissolved in a small amount of DMSO and made up to the final concentration in M9 buffer were added. The final concentration of DMSO did not exceed $1 \%$, which was not toxic to the nematodes. Nematodes $(10 \mu \ell)$ were added into the wells and plates were incubated for $2 \mathrm{~h}$, and then 7 days in the dark. Non-motile or paralysed larvae were considered dead. The number of dead and viable larvae were counted after each incubation period and the percentage of dead larvae was calculated. Levamisole 5 and $10 \mu \mathrm{g} / \mathrm{ml}$ (Sigma) was used as a positive control while untreated larvae were used as negative controls.

\section{Recovery and preparation of eggs of parasitic nematodes}

Faecal pellets were collected from lambs that were infected with either $T$. colubriformis or $H$. contortus, using sterilized harnesses and collecting bags. The eggs were prepared according to a modified version (Bizimenyera et al. 2006) of the World Association for the Advancement of Veterinary Parasitology (WAAVP) guidelines for detection of resistance in nematodes of veterinary importance (Coles, Bauer, Borgesteede, Geerts, Klei, Taylor \& Waller 1992).

\section{Anthelmintic activity against third stage larvae}

The eggs $(1 \mathrm{ml})$ were added into Petri dishes in the presence of $50 \mu$ of a suspension of E. coli (ATCC 9637) for the development of nematode larvae (Hubert \& Kerboeuf 1992) and $10 \mu \ell(50 \mu \mathrm{g} / \mathrm{ml}$ stock solution) of amphotericin B (Sigma®) to control fungal growth. The dishes were incubated for 5 days to allow the larvae to develop to the third stage (L3). The L3 larvae were frozen at $-20^{\circ} \mathrm{C}$ until needed. For the anthelmintic assay, the larvae were washed off the base of the dish with M9 buffer and treated with various concentrations of compounds and extracts of $C$. dentata in wells of a 24-well plate and incubated for $48 \mathrm{~h}$. Motile and non-motile larvae were counted to obtain the percentage inhibition of motility.

\section{RESULTS AND DISCUSSION}

\section{Inhibition of motility of adult parasitic nematodes}

The acetone and dichloromethane extracts of $C$. dentata inhibited motility of $T$. colubriformis at a concentration range of $0.16-2.5 \mathrm{mg} / \mathrm{ml}$. The lowest lethal concentration of both the acetone and dichloromethane extracts, $0.16 \mathrm{mg} / \mathrm{ml}$, led to over $60 \%$ of larvae being paralysed. The lowest tested concentration of both extracts, $0.08 \mathrm{mg} / \mathrm{ml}$, resulted in less than $10 \%$ of non-motile larvae. The inhibition of larval motility percentages by acetone extracts was very similar to that induced by the dichloromethane extracts (Fig. 1). The average survival in untreated controls was $99 \%$.

The dichloromethane extract was active against $H$. contortus at a concentration range of 0.63 to 2.5 $\mathrm{mg} / \mathrm{ml}$. About $20 \%$ average inhibition of motility of larvae resulted from a concentration of $0.63 \mathrm{mg} / \mathrm{ml}$. The acetone extract was active at a concentration range of 0.31 to $2.5 \mathrm{mg} / \mathrm{ml}$. Over $70 \%$ of the larvae were not motile after $48 \mathrm{~h}$ of incubation in the presence of $0.31 \mathrm{mg} / \mathrm{ml}$ of the acetone extract. At this concentration $(0.31 \mathrm{mg} / \mathrm{ml})$ the percentage of nonmotile larvae resulting from the acetone extract was significantly higher than that resulting from the dichloromethane extract. Concentrations of $2.5 \mathrm{mg} / \mathrm{ml}$ and $1.25 \mathrm{mg} / \mathrm{ml}$ of both acetone and dichloromethane resulted in $100 \%$ inhibition of larval motility after $48 \mathrm{~h}$ of incubation. Concentrations of both 0.16 and $0.08 \mathrm{mg} / \mathrm{ml}$ of both extracts only managed to inhibit motility of less than $10 \%$ of the larvae (Fig. 2). The average survival in untreated controls was $99 \%$.

Two compounds isolated from $C$. dentata leaves, namely, betulinic acid and lupeol were tested to evaluate their ability to paralyse $T$. colubriformis and $H$. contortus larvae. Unfortunately, ursolic acid was not isolated in sufficient quantities to test for 


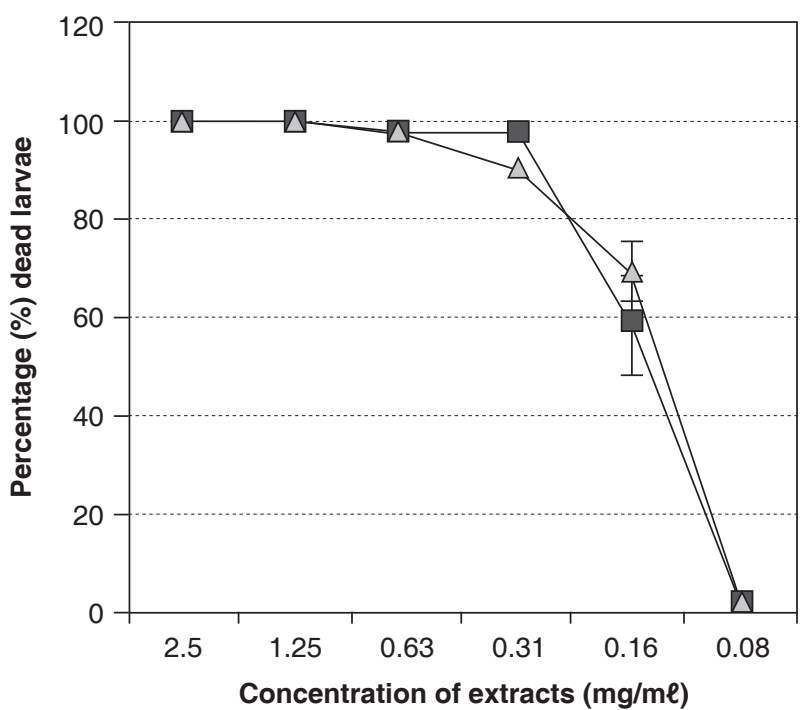

$\square-\mathrm{ACN} \quad \square$ DCM

FIG. 1 Percentage of dead T. colubriformis larvae after $48 \mathrm{~h}$ of incubation in the presence of varying concentrations of the acetone (ACN) and dichloromethane (DCM) extracts of $C$. dentata leaves

The results are means (with standard deviations) of two independent experiments performed in triplicate. The estimated $\mathrm{LC}_{50}$ value was $0.15 \mathrm{mg} / \mathrm{ml}$ for both extracts

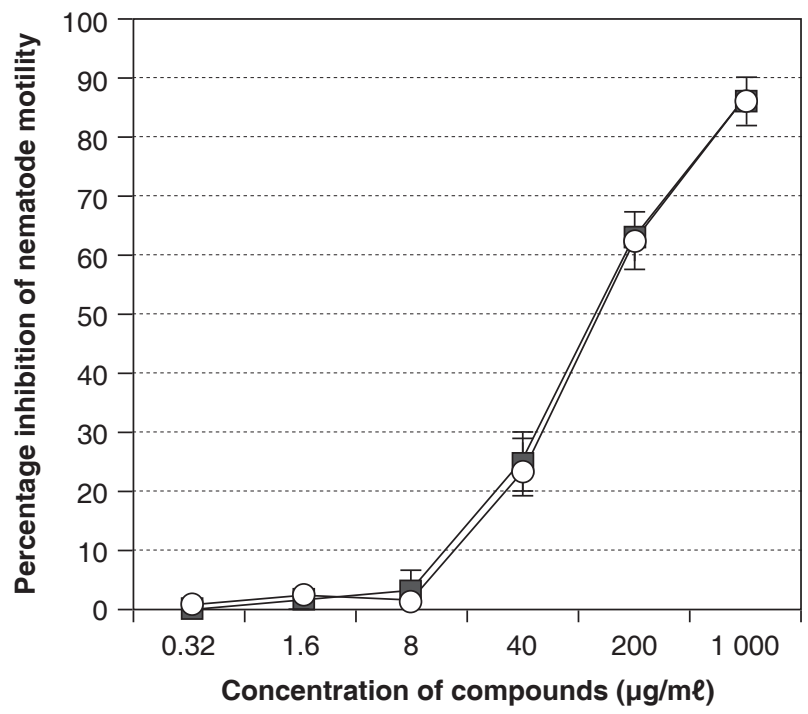

$\square-$ Betulinic acid $\quad-\mathrm{O}$ - Lupeol

FIG. 3 Percentage of dead T. colubriformis larvae after $48 \mathrm{~h}$ of incubation in the presence of varying concentrations of the lupeol and betulinic acid

The results are means and standard deviations of two independent triplicate experiments. The estimated $\mathrm{LC}_{50}$ value was $80 \mu \mathrm{g} / \mathrm{ml}$ for both lupeol and betulinic acid

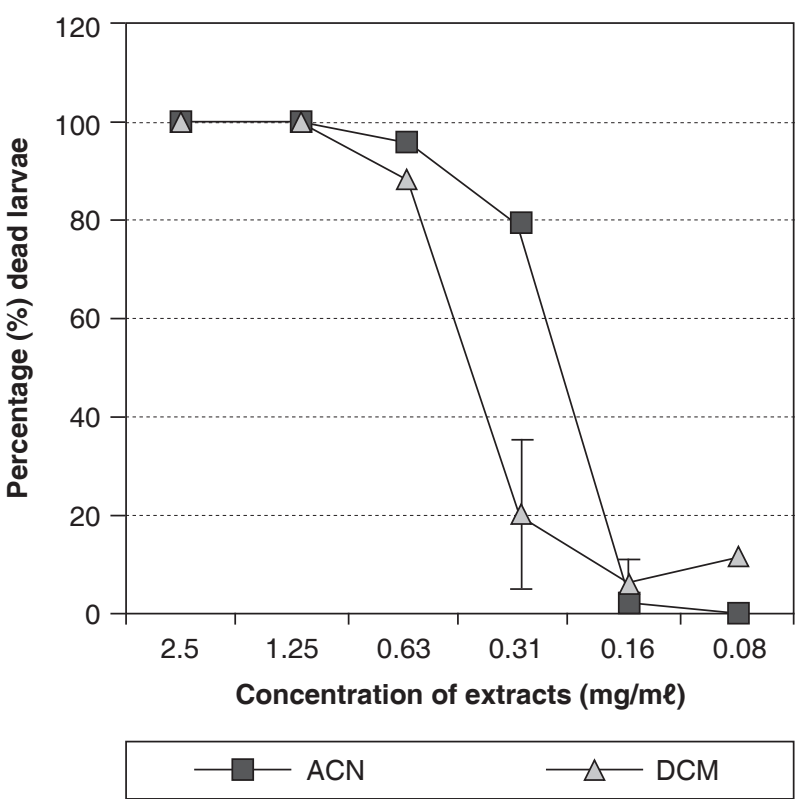

FIG. 2 Percentage of dead $H$. contortus larvae after $48 \mathrm{~h}$ of incubation in the presence of varying concentrations of the acetone (ACN) and dichloromethane (DCM) extracts of $C$. dentata leaves

The results are means (with standard deviations) of two independent experiments performed in triplicate. The estimated $\mathrm{LC}_{50}$ values were $0.2 \mathrm{mg} / \mathrm{ml}$ for acetone and $0.45 \mathrm{mg} / \mathrm{m \ell}$ for DCM extract

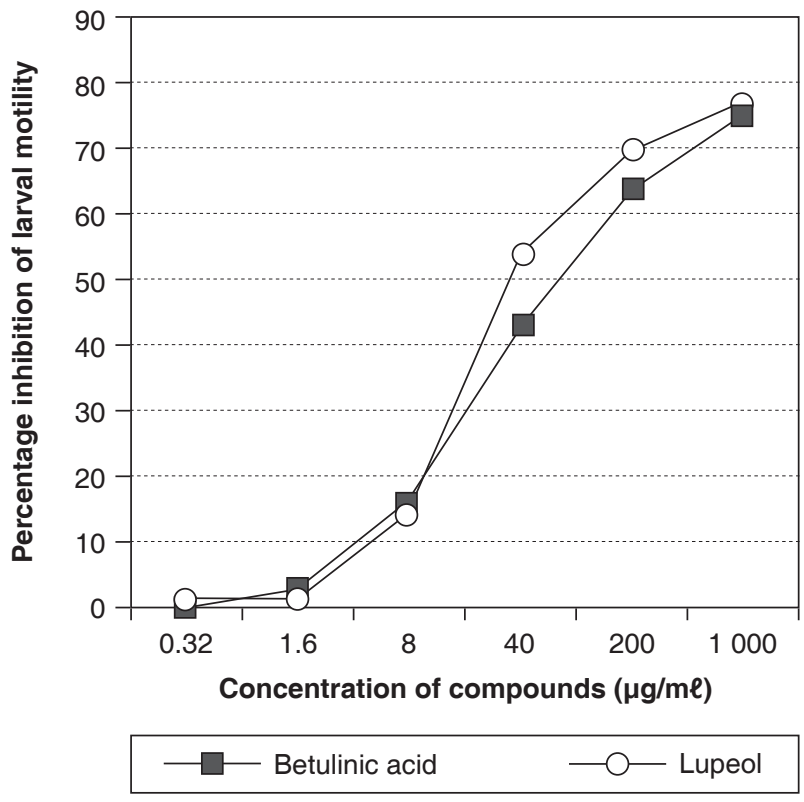

FIG. 4 Percentage of dead H. contortus larvae after $48 \mathrm{~h}$ of incubation in the presence of varying concentrations of the lupeol and betulinic acid

The results are means and standard deviations of two independent triplicate experiments. The estimated LC $_{50}$ values were $20 \mu \mathrm{g} / \mathrm{ml}$ for lupeol and $50 \mu \mathrm{g} / \mathrm{ml}$ for betulinic acid 


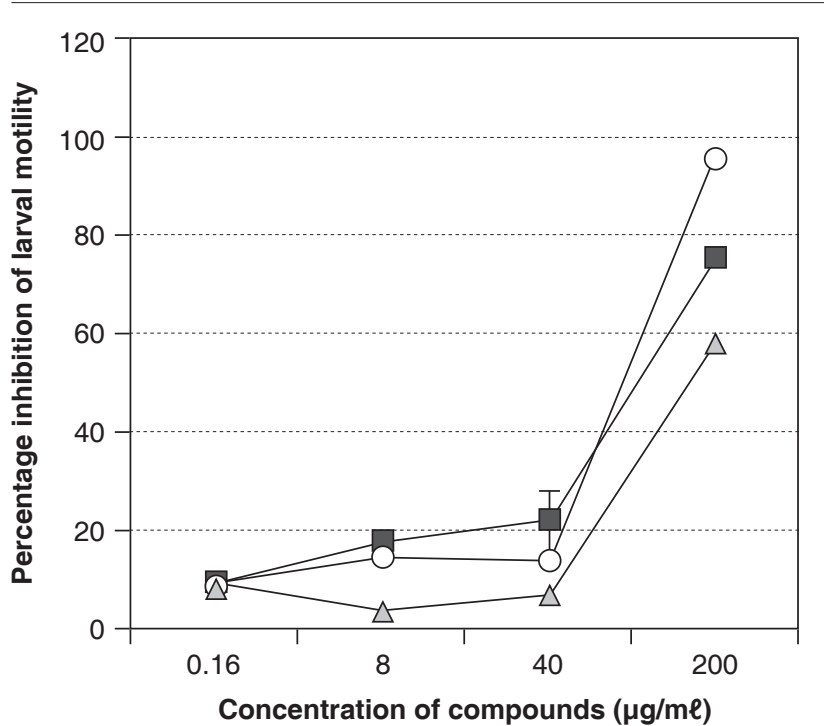

Concentration of compounds $(\mu \mathrm{g} / \mathrm{m} \ell)$

$\square-$ Betulinic acid $\quad \triangle$ Ursolic acid
$\square-$ Lupeol

FIG. 5 Inhibition of motility of free-living nematode (percentage of immotile worms), C. elegans with compounds isolated from Curtisia dentata leaves

After treatment with compounds the nematodes were incubated for $2 \mathrm{~h}$ before counting motionless larvae. The $\mathrm{LC}_{50}$ values were estimated at $120 \mu \mathrm{g} / \mathrm{m \ell}$ for lupeol, $140 \mu \mathrm{g} / \mathrm{m} \ell$ for betulinic acid and $180 \mu \mathrm{g} / \mathrm{m \ell}$ for ursolic acid

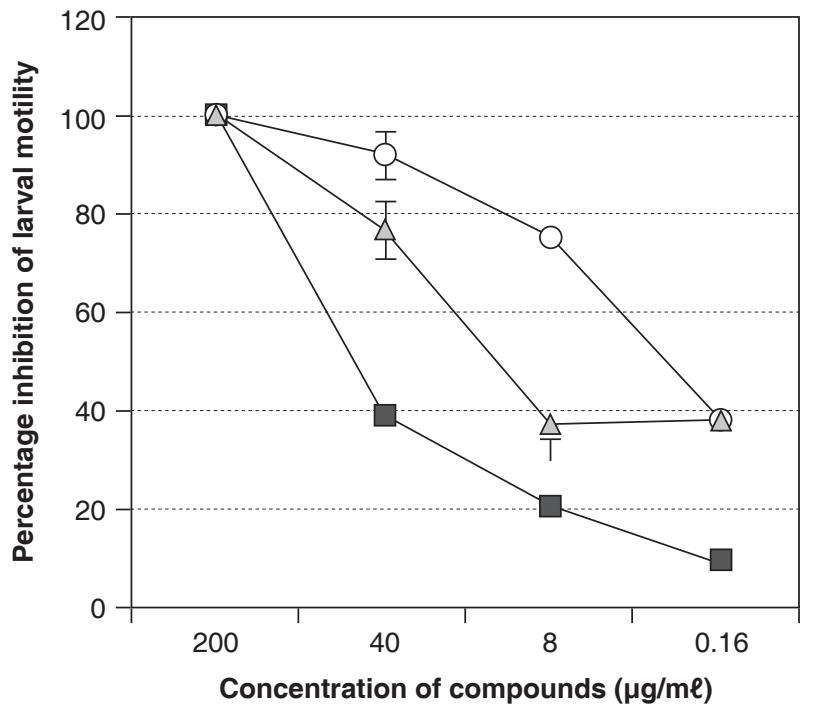

$$
\begin{aligned}
& \square-\text { Betulinic acid } \quad \triangle \text { Ursolic acid } \\
& -\square-\text { Lupeol }
\end{aligned}
$$

FIG. 7 Inhibition of motility of free-living nematode, C. elegans with isolated compounds from leaves of Curtisia dentata

After treatment with the pure compounds, the nematodes were incubated for $7 \mathrm{~d}$ before counting motionless and motile larvae. The $\mathrm{LC}_{50}$ values $2 \mu \mathrm{g} / \mathrm{ml}$ for lupeol, $70 \mu \mathrm{g} / \mathrm{m} \ell$ for betulinic acid and $12 \mu \mathrm{g} / \mathrm{m \ell}$ for ursolic acid

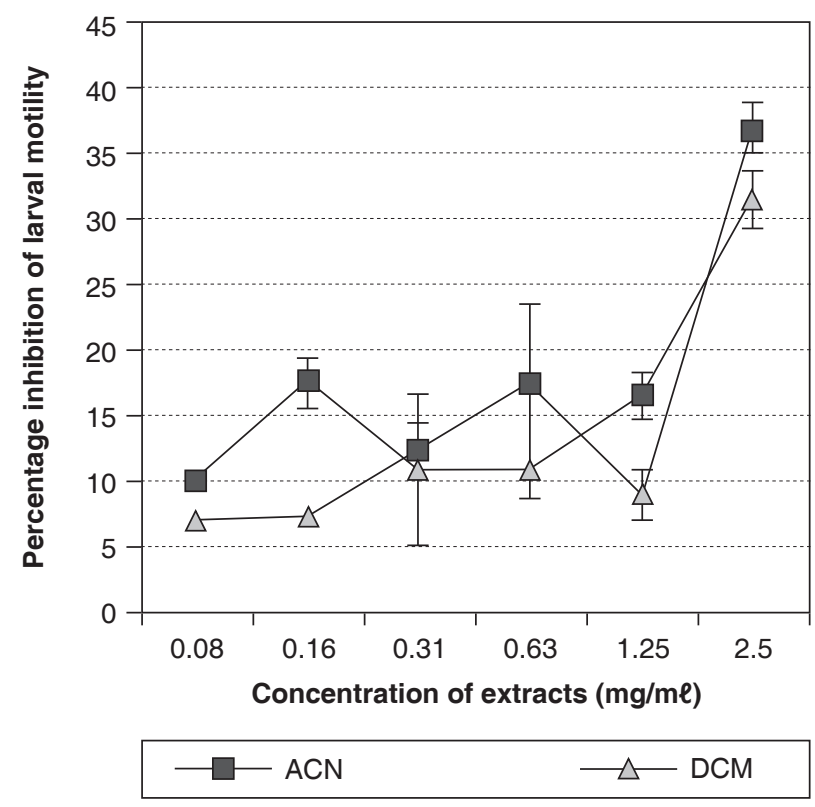

FIG. 6 Inhibition of motility of free-living nematode, C. elegans with acetone and dichloromethane of Curtisia dentata leaves

After treatment with plant extracts the nematodes were incubated for $2 \mathrm{~h}$ before counting motionless larvae

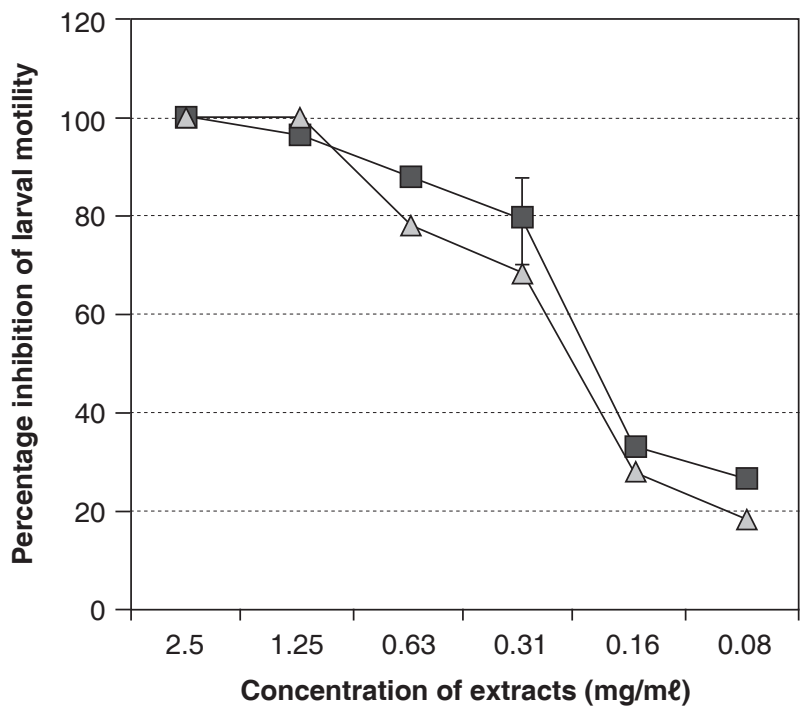

$\square-$ Acetone $\triangle$ DCM

FIG. 8 Inhibition of motility of free-living nematode, $C$. elegans with the acetone and dichloromethane extracts of the leaves of Curtisia dentata.

After treatment with the extracts, the nematodes were incubated for $7 \mathrm{~d}$ before counting of motionless and motile larvae. The calculated $\mathrm{LC}_{50}$ value was $0.2 \mathrm{mg} /$ $\mathrm{m} \ell$ for both fractions 
anti-parasitic activity. Lupeol and betulinic acid were tested at a concentration range of $0.32-1000 \mu \mathrm{g} / \mathrm{ml}$. Both compounds inhibited larval motility only at high concentrations (Fig. 3 and 4). Low concentrations did not result in appreciable numbers of motionless larvae. The average survival in untreated control of both species was $99 \%$. Lupeol and betulinic acid are poorly soluble in aqueous media. Upon mixing with water during dilution, precipitation resulted in a milky suspension, possibly making these compounds unavailable to act on the test nematode larvae. Modifications of their structures may result in more soluble derivatives of these lupane triterpenes.

The extracts showed more activity against the larvae than the isolated compounds. It would seem that, apart from lupeol and betulinic acid, other components in the extract contribute to the activity against larval motility. This emanates from the fact that betulinic acid and lupeol were, by themselves, not very active against the tested parasitic nematodes. The compounds failed to exert $100 \%$ inhibition of larval motility at all concentrations tested.

The compounds and extracts did not affect egg hatching of $H$. contortus and $T$. colubriformis (results not shown). In the controls the number of unhatched eggs was comparable to eggs treated with plant extracts and compounds. It was observed that at high concentrations $(16.7,8.3,4.17$ and $2.1 \mathrm{mg} /$ $\mathrm{ml)}$ of plant extracts no eggs or larvae were present, suggesting that lysis occurred. In concentrations where the numbers of motile larvae were low the eggs still hatched prior to paralysis.

\section{Inhibition of motility of free-living nematodes}

In vitro anthelmintic activity assay methods using $C$. elegans as the test organism provide a cheap, simple and rapid system in which broad-spectrum anthelmintic activity of plant extracts and pure compounds can be evaluated, keeping in mind the limitations of using a free-living nematode as a model for anti-parasitic activity (Eloff \& McGaw 2006). Furthermore, it has been reported that most registered deworming drugs have demonstrated activity against C. elegans, supporting the use of $C$. elegans as a model for testing compounds and plant extracts against parasitic nematodes (Simpkin \& Coles 1981).

Three compounds isolated from the dichloromethane extract of $C$. dentata, namely, lupeol, betulinic acid and ursolic acid, together with the acetone and dichloromethane extracts were assessed for ability to inhibit the motility of the free-living nematode, $C$. elegans. After $2 \mathrm{~h}$ of incubation, the highest concen- trations of isolated compounds $(200 \mu \mathrm{g} / \mathrm{ml})$ inhibited up to $90 \%$ of larval motility. Concentrations ranging from 0.16 to $40 \mu \mathrm{g} / \mathrm{ml}$ resulted in about $20 \%$ inhibition of larval motility after $2 \mathrm{~h}$ of incubation at $25^{\circ} \mathrm{C}$ (Fig. 5). The highest concentrations of extracts $(2.5$ $\mathrm{mg} / \mathrm{ml}$ ) resulted in about $35 \%$ inhibition of larval motility whereas lower concentrations ranging from 1.25 to $0.08 \mathrm{mg} / \mathrm{ml}$ resulted in less than $20 \%$ inhibition of larval motility (Fig. 6). In the untreated control $4 \%$ motionless larvae were observed after $2 \mathrm{~h}$ of incubation. In the levamisole-treated $(10 \mu \mathrm{g} / \mathrm{ml})$ controls average inhibition of larval motility was $25 \%$.

After 7 days of incubation the highest concentrations of all tested compounds resulted in $100 \%$ inhibition of larval motility. Lupeol was the most active of the isolated compounds. A concentration of $40 \mu \mathrm{g} / \mathrm{ml}$ of lupeol produced over $80 \%$ inhibition of larval motility while betulinic acid led to $40 \%$ inhibition. Ursolic acid, though less active than lupeol, produced higher inhibition of motility than betulinic acid at most concentrations tested (Fig. 7). All the compounds led to $100 \%$ paralysis of larvae at $200 \mu \mathrm{g} / \mathrm{ml}$. Enwerem et al. (2001) reported that $500 \mu \mathrm{g} / \mathrm{ml}$ of betulinic acid caused $100 \%$ paralysis of $C$. elegans larvae after 7 days in treatment. In the untreated controls approximately $85 \%$ motility was observed. In 5 and $10 \mu \mathrm{g} /$ $\mathrm{ml}$ levamisole-treated controls $65 \%$ and $48 \%$ motility were observed respectively.

Both the acetone and dichloromethane extracts of C. dentata leaves were similar in their inhibition of larval motility after 7 days of incubation, displaying a concentration-dependent effect. Concentrations ranging from 2.5 to $0.63 \mathrm{mg} / \mathrm{ml}$ of each extract led to over $80 \%$ inhibition of larval motility after 7 days of incubation. At $0.31 \mathrm{mg} / \mathrm{ml}$, both extracts led to over $60 \%$ inhibition of larval motility while lower concentrations were less effective (Fig. 8).

Several extracts of different medicinal plants show anthelmintic activity (Raj, 1975; Enwerem et al. 2001; Ademola, Fagbemi \& Idowu 2004). Hounzangbe-Adote et al. (2005) tested the in vitro effects of four tropical plants for activity against parasitic nematodes. They reported that concentrations of between 300 and $2400 \mu \mathrm{g} / \mathrm{ml}$ of ethanolic extracts of Zanthoxylum zanthoxyloides, Carica papaya, Morinda lucida and Newbouldia laevis were active against $H$. contortus. Bizimenyera et al. (2006) reported that extracts of Peltophorum africanum had in vitro activity against egg hatching and larval development of $T$. colubriformis. The $\mathrm{ED}_{50}$ values reported were $0.619 \mathrm{mg} / \mathrm{ml}$ for leaf extract, $0.383 \mathrm{mg} /$ $\mathrm{m} \ell$ for bark extract and $0.280 \mathrm{mg} / \mathrm{ml}$ for extract of the roots (Bizimenyera et al. 2006). In this study in 
vitro activity of extracts of $C$. dentata leaves was demonstrated against parasitic and free-living nematodes in a concentration-dependent manner. These results indicate that the leaves of $C$. dentata may be useful to treat helminthosis in South African folk medicine.

Despite the indication that some plant extracts are active against several nematodes, the exact mechanism remains unclear. Some compounds such as palasonin, the active principle of Butea frondosa inhibit glucose uptake and accelerate glycogen depletion in target nematodes (Kumar, Mishra, Tandan \& Tripathi 1995). The mechanism of action of many anthelmintic plant extracts may involve inhibition of energy metabolism (Dahanukar, Kulkarni \& Rege 2000).

In this study, betulinic acid induced paralysis of the tested nematodes, $C$. elegans, $H$. contortus and $T$. colubriformis at concentrations between 1000 and $200 \mu \mathrm{g} / \mathrm{ml}$. Against C. elegans, betulinic acid induced $100 \%$ paralysis at a concentration of $200 \mu \mathrm{g} /$ $\mathrm{ml}$. These results confirm the study by Enwerem et al. (2001) in which it was reported that betulinic acid isolated from Berlina grandiflora had strong activity against $C$. elegans at concentrations of 100 and $500 \mu \mathrm{g} / \mathrm{ml}$. The mechanism involved in the activity of betulinic acid against parasitic and free-living nematodes is yet to be described. Furthermore, its activity against parasitic nematodes in vivo and in vitro has not been previously demonstrated. As far as the available literature is concerned, this appears to be the first report of the effects of betulinic acid against the parasitic nematodes, $T$. colubriformis and $H$. contortus. Investigations of the in vivo activity of both the extracts of $C$. dentata and the isolated compounds may conclusively indicate their potential as anthelmintics. There was no obvious correlation between anthelmintic activity and anti-Candida activity of both extracts and isolated compounds. The calculated $\mathrm{R}^{2}$ value was 0.0132 .

The use of free-living nematodes may provide information on the activity of potential anthelmintics against parasitic nematodes. Extracts of various medicinal plant species may provide solutions to illhealth of small ruminants caused by parasitic nematodes in poor communities of southern Africa.

\section{ACKNOWLEDGEMENTS}

The National Research Foundation (NRF) provided financial support. LJ Shai is a recipient of an NRF bursary. LJ McGaw received a Claude Leon Found- ation Postdoctoral Fellowship. The Curator, Rudi Britz and staff allowed us to collect plant material in the Lowveld National Botanical Garden, Nelspruit, South Africa.

\section{REFERENCES}

ADEMOLA, I.O., FAGBEMI, B.O. \& IDOWU, S.O. 2004. Evaluation of the anthelmintic activity of Khaya senegalensis extract against gastrointestinal nematodes of sheep: In vitro and in vivo studies. Veterinary Parasitology, 122:151-164.

BIZIMENYERA, E.S., GITHIORI, J.B., ELOFF, J.N. \& SWAN, G.E. 2006. In vitro activity of Peltophorum africanum Sond. (Fabaceae) extracts on the egg hatching and larval development of the parasitic nematode Trichostrongylus colubriformis. Veterinary Parasitology, 142:336-343.

BRENNER, S. 1974. The genetics of Caenorhabditis elegans. Genetics, 77:71-94.

CHIEJINA, S.N. 2001. The epidemiology of helminth infections of domesticated animals in the tropics with emphasis on fascioliasis and parasitic gastroenteritis, in Perspectives on helminthology, edited by N. Chowdhury \& I. Tada. Enfield: Science Publishers Inc.

COlES, G.C., BAUER, C., BORGESTEEDE, F.H.M., GEERTS, S., KLEI, T.R., TAYLOR, M.A. \& WALLER, P.J. 1992. World Association for the Advancement of Veterinary Parasitology (WAAVP) methods for the detection of anthelmintic resistance in nematodes of veterinary inmportance. Veterinary Parasitology, 44:35-44.

DAHANUKAR, S.A., KULKARNI, R.A. \& REGE, N.N. 2000. Pharmacology of medicinal plants and natural products. Indian Journal of Pharmacology, 32: S81-S118.

DANØ, A.R. \& BØGH, H. 1999. Use of herbal medicines against helminths in livestock-renaissance of an old tradition. World Animal Review, 93:60-67.

DOLD, A.R. \& COCKS, M.L. 2001. Traditional veterinary medicine in the Alice district of the Eastern Cape Province, South Africa. South African Journal of Science, 97:375-379.

ELOFF, J.N. \& MCGAW, L.J. 2006. Plant extracts used to manage bacterial, fungal and parasitic infections in southern Africa, in Modern phytomedicine: turning medicinal plants into drugs, edited by I. Ahmad. Germany: Wiley-VCH.

ENWEREM, N.M., OKOGUN, J.I., WAMBEBE, C.O., OKORIE, D.A. \& AKAH, P.A. 2001. Anthelmintic activity of the stem bark extracts of Berlina grandiflora and one of its active principles, Betulinic acid. Phytomedicine, 8:112-114.

EVANS, P.H., BOWERS, W.S. \& FUNK, E.J. 1984. Identification of fungicidal and nematocidal components in the leaves of Piper betle (Piperaceae). Journal of Agriculture and Food Chemistry, 32:1254-1256.

GRIERSON, D.S. \& AFOLAYAN, A.J. 1999. An ethnobotanical study of plants used for the treatment of wounds in the Eastern Cape, South Africa. Journal of Ethnopharmacology, 67:327-332.

HAMMOND, J.A., FIELDING, D. \& BISHOP, S.C. 1997. Prospects for plant anthelmintics in tropical veterinary medicine. Veterinary Research Communications, 21:213-228.

HORAK, I.G. 2003. Parasites of domestic and wild animals in South Africa. XLII. Helminths of sheep on four farms in the Eastern Cape Province. Onderstepoort Journal of Veterinary Research, 70:175-186. 
HORAK, I.G., EVANS, U. \& PURNELL, R.E. 2004. Parasites of domestic and wild animals in South Africa. XLV. Helminths of dairy calves on dry-land Kikuyu grass pastures in the Eastern Cape Province. Onderstepoort Journal of Veterinary Research, 71:291-306.

HÖRDEGEN, P., HERTZBERG, H., HEILMANN, J., LANGHANS, W. \& MAURER, V. 2003. The anthelmintic efficacy of five plant products against gastrointestinal trichostrongylids in artificially infected lambs. Veterinary Parasitology, 117:5160 .

HOUNZANGBE-ADOTE, M.S., PAOLINI, V., FOURASTE, I., MOUTAIROU, K. \& HOSTE, H. 2005. In vitro effects of four tropical plants on three life-cycle stages of the parasitic nematode, Haemonchus contortus. Research in Veterinary Science, 78:155-160.

HUBERT, J. \& KERBEUF, D. 1992. A microlarval development assay for the detection of anthelmintic resistance in sheep nematodes. Veterinary Reviews, 130:442-446.

HUTCHINGS, A., SCOTT, A.H., LEWIS, G. \& CUNNINGHAM, A.B. 1996. Zulu medicinal plants: An inventory. Pietermaritzburg: University of Natal Press.

IDRIS, A.A., ADAM, S.E.I. \& TARTOUR, G. 1982. The anthelmintic efficacy of Artemisia herba-alba against Haemonchus contortus infection in goats. National Institute of Animal Health Quartely, 22:138-143.

IQBAL, Z., LATEEF, M., ASHRAF, M. \& JABBAR, A. 2004. Anthelmintic activity of Artemisia brevifolia in sheep. Journal of Ethnopharmacology, 93:265-268.

JABBAR, A., IQBAL, Z., KERBOEUF, D., MUHAMMAD, G., KHAN, M.N. \& AFAQ, M. 2006. Anthelmintic resistance: The state of play revisited. Life Sciences, 79:2413-2431.

KATIYAR, S.S., GORDON, V.R., MCLAUGHLIN, G.L. \& EDLIND, T.D. 1994. Antiprotozoal activities of benzimidazoles and correlations with $\beta$-tubulin sequence. Antimicrobial Agents and Chemotherapy, 38:2086-2090.

KUMAR, D., MISHRA, S.K., TANDAN, S.K. \& TRIPATHI, H.C. 1995. Possible mechanism of anthelmintic action of palasonin on Ascarida galli. Indian Journal of Pharmacology, 27: 161-168.

MCGAW, L.J., JÄGER, A.K. \& VAN STADEN, J. 2000. Antibacterial, anthelmintic and antiamoebic activity in South African medicinal plants. Journal of Ethnopharmacology, 72 : 247-263.

MURRAY, M., HUDSON, A.M. \& YASSA, V. 1992. Hepatic microsomal metabolism of the anthelmintic benzimidazole fendabendazole: enhanced inhibition of cytochrome P450 reactions by oxidized metabolites of the drug. Chemical Research and Toxicology, 5:60-66.

PADMAJA, V., THANKAMANY, V. \& HISHAM, A. 1993. Antibacterial, antifungal and anthelmintic activities of root barks of Uvaria bookeri and Uvaria narum. Journal of Ethnopharmacology, 40:181-186.

PERRY, B.D. \& RANDOLPH, T.F. 1999. Improving assessment of the economics of parasitic diseases and their control in production animals. Veterinary Parasitology, 84:145-168.

PRICHARD, R.K. 1990. Anthelmintic resistance. Veterinary Parasitology, 54:259-268.

PUJOL, J. 2000. NaturAfrica: The herbalist handbook: Africa, medicinal plants. Durban: Healers Foundation.

RAJ, R.K. 1975. Screening indigenous plants for anthelmintic activity against human Ascaris lumbricoides. Indian Journal of Physiology and Pharmacology, 19:47-49.

RASOANAIVO, P. \& RATSIMAMANGA-URVERG, S. 1993. Biological evaluation of plants with reference to the Malagasy flora. Madagascar: Napreca.

SALIFOU, S. 1996. Nematodes et nematodoses du tube digestif des petits ruminants de sud Benin: taxonomie, epidemiologie et les facteurs de variation. Ph.D. thesis, University Anta Diop.

SHAI, L.J. 2007. Characterization of compounds from Curtisia dentata (Cornaceae) active against Candida albicans. Ph.D. thesis, University of Pretoria.

SHAI, L.J., McGAW, L.J., MASOKO, P. \& ELOFF, J.N. 2008. Antifungal and antibacterial activity of seven traditionally used South African plant species active against Candida albicans. South African Journal of Botany. Digita object identifier: 10.1016/j.sajb. 2008.04.003

SHARMA, L.D. 1993. Anthelmintic efficacy of Jantana capsules in crossbred cattle. Indian Veterinary Journal, 70:459-460.

SIMPKIN, K.G. \& COLES, G.C. 1981. The use of Caenorhabditis elegans for anthelmintic screening. Journal of Chemical Technology Biotechnology, 31:66-69.

URQUHART, G.M., ARMOUR, J., DUNCAN, J.L., DUNN, A.M. \& JENNINGS F.W. 1996. Veterinary Parasitology. Oxford: Blackwell Publishers.

WOLSTENHOLME, A.J., FAIRWEATHER, I., PRICHARD, R.K., VON SAMSON-HIMMELSTJERNA. G. \& SANGSTER, N.C. 2004. Drug resistance in veterinary helminths. Trends in Parasitology, 20:515-523. 